\title{
An empirical study on the function of e-commerce to China's restructuring of foreign trade
}

\author{
LIU Xinying ${ }^{1,}$, LIU Wenwen ${ }^{2, b}$ \\ ${ }^{12}$ School of International Economics and Trade \\ Shandong University of Finance and Economics \\ Jinan, Shandong Province, China \\ a sheila_guo1988@hotmail.com, ${ }^{\mathrm{b}}$ liuwenwen888999@163.com
}

Keywords: Electronic Commerce; Foreign Trade Structure; O2O

\begin{abstract}
Information technology and network technology have been applied extensively in the field of Commerce, which made electronic commerce become the main mode of business operation. In this circumstance, the international trade transaction structure has been affected extremely. By carrying out empirical analysis between China's e-commerce market scale and China's foreign trade structure, the conclusion can be got that e-commerce plays a positive effect on the optimization of foreign trade structure of China. Put forward countermeasures from different aspects which can promote the development of e-commerce in China.
\end{abstract}

\section{Introduction}

In 2013, Chinese e-commerce market transaction scale reached 9.9 trillion, which increased 29.9 percent compared to 2012. The professionals of electronic commerce service enterprises were over 2.35 million and the employee driven indirectly by electronic commerce were more than 16.8 million. E-commerce market scale and efficiency maintain high speed growth, which reflects the strong vitality and broad development prospects of electronic commerce in China. Electronic commerce is both an opportunity and a challenge to China's foreign trade enterprises. As a big trade country, China should make self adjustments under the challenge and the opportunities of ecommerce in order to keep up with the rapid pace of global economic change. Electronic commerce as a direct result of the internet technology's development, electronic commerce is the new direction for future business development. Under this economic environment, getting a clear understanding of the impact on foreign trade structure of China from electronic commerce have a deep influence on the sustainable development of China's foreign trade.

\section{Literature Reviews about Electronic Commerce and Foreign Trade Structure}

Mann, Catherine, Sue Eckert and Sarah Cleel and Knight (2000) ${ }^{[1]}$ prospected the globalization strategy of electronic commerce, and analyzed e-commerce's impact on trade globalization. Tan Zheng, Li Shundong and Yan Lixiang (2001) ${ }^{[2]}$ discussed how to enhance enterprises competitiveness by applying e-commerce, in order to improve China's foreign trade level. $\mathrm{Hu}$ Jun $(2003)^{[3]}$ analyzed how to promote regional e-commerce from globalization, international trade, economic structure restructuring, reorganization, emerging industries and the new requirements of factor endowments. VanHoose David (2003) ${ }^{[4]}$ studied the relationship between ecommerce and international trade by the absolute advantage theory and comparative advantage theory, and pointed out that scale economy and imperfect competition can explain the intra-industry trade carried out by electronic commerce. Caroline L. Freunda and Diana Weinhold (2004) ${ }^{[5]}$ analyzed internet's impact on trade from time series and the cost structure perspectives using the empirical method. Lu Yonggang $(2005)^{[6]}$ analyzed the electronic commerce's macroscopic and microscopic effects on foreign trade, and further analyzed the electronic commerce in international economics system as a technological progress. 


\section{Empirical Analysis about Electronic Commerce and Foreign Trade Structure of China}

Data Selection. Electronic commerce began to develop rapidly in recent years in China, so choose the data from 2004 to 2012 to analysis. The explained variables are the primary goods exports of China (PC), manufactured goods exports of China (IN), processing trade exports of China (PR), general trade exports of China $(\mathrm{GE})$, and the explanatory variable is the market scale of ecommerce(EB) in China.

Unit Root Test. The stationary test should be carried out before co-integration analysis of variables. Table 1 shows the unit root test results of variables' level values and second order difference values.

Table 1 Unit Root Test of Variables

\begin{tabular}{|l|l|l|l|l|l|l|}
\hline Variables & Test Type( C,T,K) & \multirow{2}{*}{ ADF Test } & \multicolumn{3}{|l|}{ Test critical values } & \multirow{2}{*}{ Result } \\
\cline { 4 - 6 } & & & $1 \%$ level & $5 \%$ level & $10 \%$ level & \\
\hline LnEB & $(\mathrm{C}, \mathrm{T}, 1)$ & -0.170 & -4.803 & -3.403 & -2.842 & Non-stationary \\
\hline LnPC & $(\mathrm{C}, \mathrm{T}, 1)$ & -2.881 & -6.292 & -4.450 & -3.702 & Non-stationary \\
\hline LnIN & $(\mathrm{C}, \mathrm{T}, 1)$ & -2.175 & -5.835 & -4.247 & -3.591 & Non-stationary \\
\hline LnPR & $(\mathrm{C}, \mathrm{T}, 1)$ & -2.214 & -5.835 & -4.247 & -3.591 & Non-stationary \\
\hline LnGE & $(\mathrm{C}, 0,1)$ & -2.202 & -5.835 & -4.247 & -3.591 & Non-stationary \\
\hline$\Delta^{2} \operatorname{LnEB}$ & $(\mathrm{C}, 0,1)$ & -4.816 & -3.110 & -2.044 & -1.597 & Stable \\
\hline$\Delta^{2} \operatorname{LnPC}$ & $(\mathrm{C}, 0,1)$ & -4.393 & -3.110 & -2.044 & -1.597 & Stable \\
\hline$\Delta^{2} \operatorname{LnIN}$ & $(\mathrm{C}, 0,1)$ & -3.647 & -3.007 & -2.021 & -1.597 & Stable \\
\hline$\Delta^{2} \operatorname{LnPR}$ & $(\mathrm{C}, 0,1)$ & -3.463 & -3.007 & -2.021 & -1.597 & Stable \\
\hline$\Delta^{2} L n G E$ & $(\mathrm{C}, 0,1)$ & -2.597 & -3.110 & -2.044 & -1.597 & Stable \\
\hline
\end{tabular}

Note: $\Delta^{2}$ means second order difference. C, T, K represent constant term, the trend term and the lag order term respectively, 0 means this term is not included.

The level values of variables are non-stationary, and the second order difference values of variables are stable. Therefore, the co-integration analysis of the variables can be carried out.

Co-integration Analysis. Carry out co-integration analysis on variables, and the estimation results are as follows:

$\operatorname{LnPC}=0.412327 * \operatorname{LnEB}+6.077889+E$.

(118.0635) (10.00054)

$R^{2}=0.93 \quad$ D.W. $=2.75$.

$\operatorname{LnIN}=0.541579 * \operatorname{LnEB}+8.786236+E$.

$(132.6812)(10.21143)$

$R^{2}=0.94 \quad$ D.W. $=1.45$

$L n P R=0.411025 * \operatorname{LnEB}+8.263935+E$.

$(135.8533) \quad(8.436635)$ 


$$
\begin{aligned}
& R^{2}=0.91 \quad \text { D.W. }=1.30 \\
& L n G E=0.609818 * \operatorname{LnEB}+7.965817+E .
\end{aligned}
$$

$$
(106.5634) \quad(10.18582)
$$

$$
R^{2}=0.94 \quad D . W .=1.65
$$

The goodness of fit of the equation is fit and all indicators are tested. The coefficients before LnEB are positive, which indicates there is a positive correlation between the development of Ecommerce and export trade of China. Test the stability of the residual, and the result shows that the residual is stable. So there is a co-integration relationship among variables.

Error Correction Model of the Variables. Even there is a long-term equilibrium relationship between two variables, but in the short term the unbalance factors may exist due to external interference. This kind of short-term imbalances can be corrected by error correction model. The equations of error correction model are as follows:

$$
\begin{aligned}
& \Delta L n P C=-0.11372+0.84129 \Delta \operatorname{LnEB}-1.27022 E C M(-1)+\varepsilon . \\
& (-0.542854) \quad(1.127348) \quad(-2.769069) \\
& R^{2}=0.76 \quad \text { S.E. }=0.09 \\
& \Delta L n I N=-0.106116+0.970688 \Delta L n E B-0.743672 E C M(-1)+\varepsilon . \\
& (-0.427478) \quad(1.09903) \quad(-1.754506) \\
& R^{2}=0.56 \quad \text { S.E. }=0.12 \\
& \triangle L n P R=-0.129571+0.927289 \Delta L n E B-0.681803 E C M(-1)+\varepsilon . \\
& (-0.60454) \quad(1.218395) \quad(-1.682514) \\
& R^{2}=0.58 \quad \text { S.E. }=0.10 \\
& \Delta L n G E=-0.106133+0.532157 \Delta \operatorname{LnEB}-0.827787 E C M(-1)+\varepsilon . \\
& (-0.361128) \quad(0.456912) \quad(-1.865792) \\
& R^{2}=0.56 \quad \text { S.E. }=0.14
\end{aligned}
$$

ECM stands for error correction term. The explained variables' fluctuations can be divided into short-term equilibrium and long-term equilibrium, and the short-term fluctuations are reflected by difference term of variables, the long-term equilibrium is reflected by the error correction terms. In the short term, the change of e-commerce transaction volume will lead to the same direction change of China's export trade. The error correction term will revise the short-term deviation of China's export trade. 


\section{Conclusion}

There is a positive relation between China's e-commerce market transaction scale and the primary goods exports, manufactured goods export, processing trade exports and general trade exports of China from a long-term perspective. China's e-commerce market transaction volume increase one unit, and the primary goods exports, manufactured goods export, processing trade exports and general trade exports of China will increase by $0.41,0.54,0.41$ and 0.61 units. Among them, the e-commerce transaction volume has a lager impact on manufactured goods export and general trade exports, which means e-commerce has a positive effect on China's export trade structure's optimization and restructure.

There is a positive relation between China's e-commerce market transaction scale and the primary goods exports, manufactured goods export, processing trade exports and general trade exports of China from a short-term perspective. China's e-commerce market transaction volume increase one unit, and the primary goods exports, manufactured goods export, processing trade exports and general trade exports of China will increase by $0.84,0.97,0.93$ and 0.53 units. Among them, the e-commerce transaction volume has a lager impact on manufactured goods export and processing trade exports, which show that the e-commerce's development needs the support of processing trade. When Short term fluctuations deviate from the long-term equilibrium, the error correction term will revise the primary goods exports, manufactured goods export, processing trade exports and general trade exports situation by the intensity of $1.27,0.74$, 0.68 and 0.83 . Processing trade exports' error correction effect is the weakest, the relative to other forms of trade, which means that more effective monitoring measures are needed to guarantee the development of processing trade exports. It also reflects that there are many unstable factors in the development of China's processing trade, and China's trade structure need optimization and restructure.

\section{Acknowledgements}

This work was financially supported by the Shandong Provincial Science and Technology Development Planning project(2014GGH213001), Shandong Provincial Natural Science Foundation project(ZR2013GM013), Shandong Provincial Academy of Social Sciences project(14AWTJ01-15), Shandong Education Department's Project (sdyy11201), Project (jy201212).

\section{References}

[1] Mann, Catherine, Sue Eckert, Sarah Cleel and Knight: Global Electronic Commerce: A Policy Primer (Peterson Institute, USA 2000).

[2] Tan Zheng, Li Shundong and Yan Lixiang: E-commerce and international trade (Posts and Telecom Press, Bei Jing 2001).

[3] Hu Jun: China-Asian Free Trade Area Electronic Commerce Framework (Guang Xi university, Guang Xi 2003).

[4] VanHoose David: E.commerce Economics (Thomson Learning Press, Canada 2003).

[5] Caroline L. Freund and Diana Weinhold: The effect of the Internet on international trade, Journal of International Economics, Vol.9, NO.2, 2004,pp:171-189. 
[6] Lu Yonggang: Study on the Innovation of E-business to International Trade (University of International Business and Economics, Bei Jing 2005). 